\title{
Hepatitis screening extended
}

\section{Washington}

SPURRED by growing concern that non-A and non- $\mathrm{B}$ hepatitis may represent a more serious health hazard than previously thought, the American Association of Blood Banks (AABB) announced last week that its members will begin screening all donated blood for evidence of nonA, non-B hepatitis. But as AABB officials are quick to acknowledge, such screening leaves much to be desired, as no direct tests for non-A, non-B hepatitis exists.

Blood banks hope to get an indirect indication of the potential for a donor to transmit non- $\mathrm{A}$, non-B hepatitis by using two different blood tests. One measures the level of alanine amino transferase (ALT), commonly used as an indicator of liver dysfunction. The other tests for the presence of antibodies to hepatitis-B core antigen (anti-HBc). High levels of donor ALT and the presence of anti-HBc both correlate with subsequent development of non-A, non-B hepatitis.

The debate over whether to use one or both of these tests to screen donated blood has been raging for years. The ubiquity of non- $\mathrm{A}$, non- $\mathrm{B}$ hepatitis as the cause of post-transfusion hepatitis became clear only after the development of a test for hepatitis-B surface antigen in the early 1970s. Between 7 and 17 per cent of all transfusion recipients develop posttransfusion hepatitis. Now, with effective screening for hepatitis-B, non-A, non-B hepatitis is estimated to account for more than 90 per cent of these cases. Even before such screening, Stephen Feinstone of the laboratory of infectious diseases at the National Institutes of Health (NIH) estimates that two-thirds of post-transfusion hepatitis cases were non- $\mathbf{A}$; non- $\mathbf{B}$.

The American Red Cross is also implementing ALT testing at its blood banks; the programme began on $7 \mathrm{July}$, and is expected to be completed by 1 October. $\mathrm{AABB}$ expects to implement testing in its member centres by 30 November. A third organization for blood banks, the Council for Community Blood Centers (CCBC) accounting for approximately one quarter of all blood collections, has not officially declared a position on ALT testing. But its president, Richard Counts of the Puget Sound Blood Center, says most members will go ahead with ALT screening.

Far more contentious is the use of anti$\mathrm{HBc}$ testing. A study of post-transfusion non- $\mathrm{A}$, non-B hepatitis in 481 recipients by Harvey Alter and associates at NIH showed (Annals of Internal Medicine 104, $488 ; 1986)$ that 11.9 per cent developed non-A, non-B hepatitis after receiving blood from donors positive for anti-HBc, compared with 4.2 per cent among recipients for blood negative for anti-HBc.
Alter estimated that prospective anti$\mathrm{HBc}$ screening could eliminate 43 per cent of non-A, non-B hepatitis cases, while losing only 4 per cent of donors. Joseph Bove, chairman of AABB's committee on transfusion-transmitted diseases, argues that, taken with ALT screening, anti-HBc will go a long way towards reducing non$\mathrm{A}$, non-B hepatitis. Bove also argues that anti-HBc will be a useful "second line of defense" in screening for hepatitis-B. But Bove admits that there is no good biological reason to explain why people with antibodies to hepatitis-B core antigens should be more likely to transmit non-A, non-B hepatitis. The same positive relationship does not exist between hepatitis-B surface antibodies and transmission of non- $A$, non-B hepatitis.

Robert AuBuchon of the American Red Cross says the Red Cross is planning to start an anti-HBc screening programme of its own, but not until after the ALT test is implemented. Counts feels that the Food and Drug Administration should play a larger role in certifying the usefulness of anti-BHc. Counts also points out that Alter's study used a radioimmunoassay for anti-HBc testing, whereas an enzyme-linked assay is more likely to be utilized in a large screening programme. A further concern is that once implemented, screening tests are hard to dispense with. The Red Cross had planned a prospective clinical trial of non-A, non-B hepatitis screening techniques, but were daunted by the size of the project, and the possible ethical problems of giving unscreened blood to recipients.

What everyone is hoping for is a direct test for the agent causing non-A, non-B hepatitis, but that seems a long way off. Several candidates have been suggested, but none has held up. A major hurdle is tracking down the causative agent is its low concentration in blood - as much as 10,000 times less than hepatitis-B virus and the lack of a suitable animal model for the disease. Only chimpanzees have been successfully infected with non-A, non-B hepatitis.

A major concern for all blood centres will be the loss of donors from false positives from the ALT and anti-BHc tests. Between 4 and 7 per cent of donors are expected to be prevented from giving blood. This comes at a time when screening for antibodies to the AIDS virus has already had a negative impact on the blood supply. The test will also increase the cost of a unit of blood by about $\$ 3$. Despite the additional cost and the loss of donors, AABB president Eugene Berkman says the tests are "essential to increase the safety of the blood supply".

\section{Good prospects for lion tamarins}

\section{Washington}

Brighter days may lie ahead for the golden-headed lion tamarin (Leontopithecus chrysomelas). The National Zoo here in Washington recorded the first birth last

\section{IMAGE UNAVAILABLE FOR COPYRIGHT REASONS}

month in a captive breeding programme established to restore numbers of the endangered species.

Golden-headed lion tamarins have recently been the object of a worldwide conservation effort (see Nature 322, 586; 1986). The Washington infant's parents are themselves well travelled. They were part of a group of 16 golden-headed lion tamarins imported by a Belgian animal dealer in the winter of 1983 just before Belgium signed the Convention on International Trade in Endangered Species. The animals were ultimately repatriated to Brazil in November 1985 but were not released into the wild. Instead, an International Recovery and Management Committee for the tamarins, co-chaired by Jeremy J.C. Mallinson of the Jersey Wildlife Preservation Trust and Adelmar CoimbraFilho of the Rio de Janeiro Primate Center, decided that the animals should be included in a captive breeding programme to be conducted both in Brazil and at several locations in North America.

Last March, a total of $\mathbf{2 0}$ golden-headed lion tamarins, including the 16 recovered from Belgium, were sent to the National Zoo in Washington and the Los Angeles Zoo. The National Zoo subsequently sent four animals to the Brookfield Zoo in Chicago. Under the terms of the breeding programme, all the US animals remain the property of Brazil, and may some day be included in a programme to reintroduce them to their natural habitat.

Devra Kleiman of the National Zoo, who is a member of the international management committee, says that until there is a better monitoring programme for wild golden-headed lion tamarins, it would be a mistake to release the captive population. In addition to the one birth, two other tamarins at the National Zoo appear to be pregnant. "Consider these as genes in the bank”, says Kleiman. Joseph Palca 